\title{
Upaya Meningkatkan Motivasi dan Hasil Belajar Siswa Pada Mata Pelajaran Matematika Melalui Tutorial Pembelajaran Berbasis Ispring di Kelas X SMAN 10 GARUT
}

\author{
Hikmat Arief", Ecep Andang ${ }^{\# 2}$, Enung Nurjanah ${ }^{\# 3}$, Yuan Risnandah ${ }^{\# 4}$ \\ ${ }^{\#}$ Institut Pendidikan Indonesia GARUT \\ Jl. Terusan Pahlawan No.32, RW.01, Sukagalih, Kec. Tarogong Kidul, Kabupaten Garut, Jawa Barat 44151 \\ ${ }^{1}$ hikmatasgar@gmail.com, hikmat arief mhs@institutpendidikan.ac.id \\ ecep_andang_mulyana_mhseinstitutpendidikan.ac.id \\ senün@institutPendidikan.ac.id \\ ${ }^{4}$ yuan_risnandah_mhs@institutpendidikan.ac.id
}

\begin{abstract}
The development of technology and information is increasingly advanced, making available computer-based technology can be applied in the world of education. The use of computer technology is used for learning media or learning resources. In fact, many learning resources are circulating online in the form of e-learning to facilitate the delivery of learning materials, this material is packaged in an attractive manner in the delivery of learning materials, so this material is packaged attractively in an application that is educational for them. The purpose of this study was to make a variety of online learning for students using multimedia-based learning applications as a means to be faster in introducing mathematics to high school students to find out to what extent the use of Ispring-based multimedia can be used in learning the absolute value equality in Mathematics subjects. The writing method used is the method of observation and literature study as well as an alternative to online learning. The application used is Ispring. Hopefully using Ispring can improve the ability to learn Absolute Value Equations in mathematics lessons.
\end{abstract}

Keywords: Ispring-Based Learning Tutorial, Learning Motivation, Learning Outcomes

Abstrak - Perkembangan teknologi dan informasi yang semakin maju, menjadikan teknologi berbasis komputer yang tersedia dapat diterapkan dalam dunia pendidikan. Penggunaan teknologi komputer digunakan untuk media pembelajaran atau sumber belajar. Faktanya banyak sumber belajar yang beredar secara online dalam bentuk e-learning untuk memudahkan penyampaian materi pembelajaran, materi ini dikemas secara menarik dalam penyampaian materi pembelajaran, sehingga materi ini dikemas secara menarik dalam sebuah aplikasi yaitu mendidik untuk mereka. Tujuan dari penelitian ini adalah membuat berbagai pembelajaran online bagi siswa dengan menggunakan aplikasi pembelajaran berbasis multimedia sebagai sarana agar lebih cepat dalam mengenalkan matematika kepada siswa SMA untuk mengetahui sejauh mana penggunaan multimedia berbasis Ispring dapat digunakan. dalam pembelajaran persamaan nilai absolut pada mata pelajaran Matematika. Metode penulisan yang digunakan adalah metode observasi dan studi pustaka serta alternatif pembelajaran online. Aplikasi yang digunakan adalah Ispring. Semoga dengan menggunakan Ispring dapat meningkatkan kemampuan mempelajari Persamaan Nilai Mutlak dalam pelajaran matematika.

Kata Kunci: Tutorial Pembelajaran Berbasis Ispring, Motivasi Belajar, Hasil Belajar

\section{Pendahuluan}

Pendidikan merupakan suatu usaha sadar yang dilakukan secara sengaja untuk mencerdaskan suatu kelompok atau suatu bangsa. Wujud nyata dari proses pendidikan adalah dalam bentuk proses pembelajaran. Pembelajaran adalah proses interaksi peserta didik dengan pendidik dan sumber belajar pada suatu lingkungan belajar. Tujuan pembelajaran adalah tercapainya kemampuan (kompetensi) atau keterampilan yang diharapkan dapat dimiliki oleh siswa setelah mereka melakukan proses pembelajaran tertentu [1].
Di dalam proses pembelajaran terdapat berbagai faktor yang dapat mempengaruhi terhadap keberhasilan pencapaian kompetensi dan tujuan pembelajaran. Faktor-faktor tersebut diantaranya adalah faktor intern (yang berasal dari dalam diri peserta didik) seperti intelegensi, kesehatan jasmani, motivasi, dan minat. Faktor selanjutnya adalah faktor ekstern (yang berasal dari lingkungan luar peserta didik) seperti kondisi ekonomi keluarga, sosial, sarana dan prasarana sekolah, serta latar belakang pendidikan keluarga.

Pendidikan nasional di Indonesia diselenggarakan dalam berbagai jenjang pendidikan yang mencakup pendidikan 
formal, pendidikan non formal, dan pendidikan informal. Salah satu jenjang pendidikan tersebut adalah pendidikan formal yang meliputi pendidikan dasar, pendidikan menengah, dan pendidikan tinggi yang pelaksanaannya berpedoman pada kurikulum yang telah ditetapkan sesuai dengan jenjang pendidikannya.Salah satu jenjang pendidikan formal yang ada di Indonesia adalah pendidikan menengah, yaitu jenjang pendidikan yang menitikberatkan pada aspek pengembangan siswa secara pribadi yang bertujuan untuk meningkatkan kemampuan siswa sebagai anggota masyarakat dalam mengimplementasikan teori-teori yang diperoleh secara formal di sekolah melalui hubungan interaksi dengan lingkungan sosial budaya dan alam sekitarnya.

Pendidikan di sekolah tidak terlepas dari proses kegiatan belajar mengajar yang merupakan perencanaan secara sistematis yang dibuat oleh guru dalam bentuk Rencana Pelaksanaan Pembelajaran (RPP). Sebagai usaha sadar untuk meningkatkan kualitas pendidikan, seorang guru tentunya memerlukan strategi dan metode penyampaian materi yang tepat dalam mendisain suatu kegiatan pembelajaran yang dapat merangsang motivasi siswa dalam belajar sehingga didapatkan output yang diharapkan yaitu berupa hasil belajar yang sesuai dengan tujuan pembelajaran

Berdasarkan UU Nomor 20 Tahun 2003 penjelasan Pasal 37 Ayat 1 ditegaskan bahwa Pendidikan Kewarganegaraan dimaksudkan untuk membentuk peserta didik menjadi manusia yang memiliki rasa kebangsaan dan cinta tanah air. Menurut Peraturan Pemerintah No. 22 Tahun 2006 tentang Standar Isi menyebutkan bahwa Pendidikan Kewarganegaraan merupakan mata pelajaran yang memfokuskan pada pembentukan warga negara yang memahami dan mampu melaksanakan hak-hak dan kewajibannya untuk menjadi warga negara Indonesia yang cerdas, terampil, dan berkarakter yang diamanatkan oleh Pancasila dan UUD 1945.

Permendiknas No. 41 Tahun 2007 tentang Standar Proses untuk Satuan Pendidikan Dasar dan Menengah menjelaskan bahwa Standar Proses meliputi perencanaan proses pembelajaran, pelaksanaan proses pembelajaran, penilaian hasil pembelajaran, dan pengawasan proses pembelajaran untuk terlaksananya proses pembelajaran yang efektif dan efisien. Proses pembelajaran pada setiap satuan pendidikan dasar dan menengah harus interaktif, inspiratif, menyenangkan, menantang, dan memotivasi peserta didik untuk berpartisipasi aktif, serta memberikan ruang yang cukup bagi prakarsa, kreativitas, dan kemandirian sesuai dengan bakat, minat, dan perkembangan fisik serta psikologis peserta didik.

Komponen yang menjadi sasaran peningkatan kualitas pendidikan adalah sistem pembelajaran di kelas. Proses pembelajaran merupakan tanggung jawab guru sebagai acuan dalam mengembangkan segala potensi yang ada pada peserta didik. Tujuan utama dari proses pembelajaran adalah untuk mengubah perilaku peserta didik berdasarkan tujuan yang telah direncanakan dan disusun oleh guru sebelum proses pembelajaran berlangsung. Perubahan prilaku itu mencakup beberapa aspek intelektual, sikap, dan keterampilan [2].

Kemajuan teknologi informasi memiliki banyak dampak positif bagi kemajuan pendidikan orang dewasa ini, khususnya komputer dan teknologi internet, baik dari segi hardware maupun Software Kemajuan teknologi memberikan banyak tawaran dan pilihan bagi dunia pendidikan untuk mendukung proses pembelajaran sehingga pembelajaran menjadi lebih efektif dan efisien bagi peserta didik.. Keuntungan Apa yang ditawarkan dalam kemajuan teknologi tidak hanya terletak pada faktor kecepatan memperoleh informasi tetapi juga pada fasilitas multimedia yang dapat menjadikan pembelajaran lebih menarik, visual dan interaktif [3].

Pendidikan merupakan investasi yang berharga bagi suatu peradaban, selain itu pendidikan memegang peranan yang sangat vital dalam setiap sektor kehidupan. [4]. Berbagai upaya telah dilakukan oleh pemerintah dalam meningkatkan kualitas pendidikan nasional, antara lain pemutakhiran kurikulum, peningkatan kualitas tenaga pengajar, penataan manajemen pendidikan dan penerapan teknologi informasi pendidikan [5].

Dalam pendidikan peranan pembelajaran matematika sangat penting, selain matematika tumbuh dan berkembang untuk dirinya sendiri juga melayani pengetahuanpengetahuan lain dalam perkembangan dan operasinya [6] Kedudukan matematika sebagai "Ratu Ilmu Pengetahuan" membuat ilmu-ilmu lain tidak lepas dari matematika

[7][7] Perkembangan matematika tidak bergantung pada ilmu lain, tetapi sebaliknya ilmu lain seperti fisika, kimia, biologi dan ilmu lainnya berkembang dari dasar-dasar konsep ilmiah matematika.

Proses pembelajaran ini menjadi tanggung jawab guru untuk mengembangkan segala potensi yang ada pada siswa [8]. Tujuan utama dari proses pembelajaran adalah untuk berubah sifat dan perilaku peserta didik berdasarkan tujuan yang telah direncanakan dan disusun oleh guru sebelum proses pembelajaran berlangsung. Perubahan perilaku ini mencakup aspek intelektual [9].

[10] Teknologi pendidikan dalam istilah bahasa Inggris adalah "instructional technolgy" atau "Education Technology". Pendidikan sejenis ini diutamakan Yang merupakan media sebagai komunikasi yang berkembang sangat pesat dan dapat dimanfaatkan dalam dunia pendidikan. Alat-alat teknologi tersebut Yang dimaksud dengan "Hardware" antara lain TV, radio, video, tape, komputer dan lain-lain. Peranan Pendidikan yang menggunakan media teknologi disebut itu "software", diantaranya menganalisis dan merancang urutan atau langkah-langkah pembelajaran berdasarkan tujuan yang di 
harapkan tercapai dengan metode penyampaian materi yang serasi dengan kebutuhan siswa dan penilaian keberhasilannya. [11], [7].

Pemanfaatan e-learning dalam proses pembelajaran misalnya adalah dengan menggunakan media pembelajaran berbantuan ispring. Pembelajaran berbantuan Ispring, yaitu penggunaan internet yang memadukan antara belajar jarak jauh dan tatap muka konvensional. Pada ispring sebagian bahan belajar, diskusi, konsultasi, penugasan, dan latihan disampaikan melalui internet, sedangkan ujian dan sebagian konsultasi, diskusi, dan latihan dilakukan secara tatap muka [12]. Media pembelajaran yang semula menggunakan papan tulis dan kapur beralih ke penggunaan komputer, LCD, kamera video digital dan lainnya serta dari metode pembelajaran yang semula bertatap muka secara langsung sedikit demi sedikit bergerak menuju ke pembelajaran virtual [13].

Manfaat dari proses pembelajaran yang dilakukan dengan bantuan ispring tersebut adalah dapat mengatasi berbagai kendala dalam pembelajaran konvensional terutama keterbatasan materi ajar, sumber belajar dan waktu dapat dimediasi dengan bantuan ispring pembelajaran. Proses pembelajaran berbantuan ispring ini, bagi dosen dapat mengunggah peta konsep, tujuan pembelajaran dan beberapa pertanyaan apersepsi dalam suatu situs atau website, sehingga siswa dapat mengaksesnya sebelum perkuliahan berlangsung. Tujuannya agar siswa telah mempersiapkan diri sebelum kuliah berlangsung sehingga pembelajaran dapat berlangsung lebih optimal. Melalui penggunaan website, mahasiswa dapat mengakses materi sesering yang dibutuhkan agar bisa mengulang materi yang belum dipahami [14].

[15] menyatakan bahwa Pembelajaran TIK terbagi menjadi: (1) komputer sebagai pembelajaran, (2) internet sebagai media pembelajaran. Pembelajaran berbasis TIK biasanya menggunakan perangkat hardware dan software dalam aplikasinya, selain itu juga didukung oleh jaringan internet [16], [5].

Ada beberapa langkah yang bisa dilakukan oleh seorang guru baik untuk meningkatkan motivasi peserta didik atau pun mampu meningkatkan hasil belajar peserta didik, yaitu diantaranya mencoba mengubah cara metode mengajar dari metode ceramah ke metode pembelajaran interaktif seperti model tutorial, game's, simulasi atau drill [17], [18]. Dengan metode interaktif ini diharapkan dapat menigkatkan motivasi hasil belajar siswa. Dan pada saat ini guru-guru di SMA NEGERI 10 Garut dalam proses belajar mengajar masih menggunakan metode ceramah, jarang sekali guruguru menggunakan media power point dan LCD projector. Dan dari hasil pengamatan di SMA NEGERI 10 Garut, belum terdapat guru yang menggunakan media pembelajaran berbasis ispring [19].

Penulisan artikel ini dilakukan dengan cara observasi dan studi pustaka yaitu dengan cara menelusuri berbagai arikel ilmiah dan jurnal yang berhubungan dengan "Upaya Meningkatkan Motivasi dan Hasil Belajar Siswa Pada Mata Pelajaran Matematika Melalui Tutorial Pembelajaran Berbasis Ispring". Setelah itu penulis menyeleksi dan melakukan pecobaan pada siswa dengan Ispring pada saat Penilaian Akhir Tahun.

\section{Tinjauan Pustaka}

\section{A. Persamaan nilai mutlak}

Seorang anak bermain lompat-lompatan di lapangan. Dari posisi diam anak tersebut melompat 5 langkah kedepan, kemudian 7 langkah ke belakang, dilanjutkan 4 langkah ke depan, dan akhirnya 6 langkah kebelakang.

\section{Permasalahan}

1. Dapatkah anda membuat sketsa lompatan anak?

2. Tentukan posisi akhir anak tersebut!

3. Berapa banyak langkah yang diambil anak?

\section{Penyelesaian}

Kita mendeskripsikan maju kedepan searah sumbu $\mathrm{X}$ positif dan kebelakang sepanjang sumbu $X$. negatif. sketsa berikut!

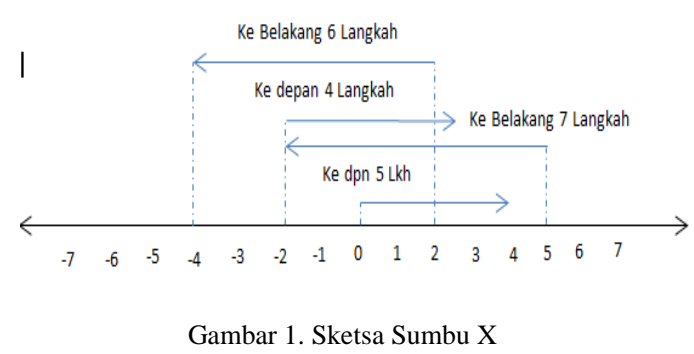

Misalkan $\mathrm{X}=0$ posisi awal anak. Anak panah yang pertama diatas bilangan menunjukan langkah pertama anak sejauh 5 langkah maju (mengarah ke sumbu X positif atau + 5, anak panah kedua menunjukan 7 langkah anak kebelakang (mengarah ke sumbu X negatif atau - 7) dari posisi akhir langkah, demikian seterusnya.

Berdasarkan sketsa tersebut dapat dilihat pergerakan akhir dari posisi awal 4 langkah kebelakang $(X=5+(-7)$ $+4+(-6)=-4)$. Banyak langkah diambil anak adalah konsep nilai mutlak karena banyak langkahnya saja yang di hitung bukan arahnya. Jumlah langkah dapat diwakili oleh nilai mutlak dari sebuah angka bulat.

Banyak langkah tersebut adalah sebagai berikut.

Banyak langkah $=|5|+|-7|+|4|+|-6|=$ 22 langkah

Nilai mutlak x akan memiliki nilai positif atau nol (nonnegatif). Secara geometris, nilai mutlak sebuah angka adalah jarak antara angka itu dan nol pada garis bilangan real. Jadi, nilai mutlak sebuah angka tidak mungkin memiliki nilai negatif, tetapi mungkin memiliki nilai nol.

Berikut adalah contoh percobaan adalah perpindahan posisi pada garis bilangan 
1. $|2|$

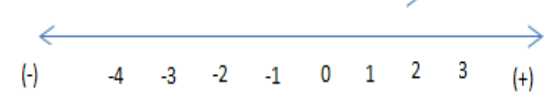

2. $|-4|$

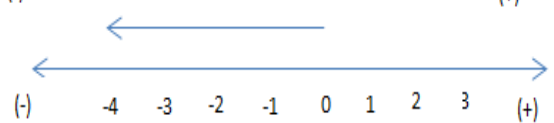

Gambar 2. Perpindahan posisi garis bilangan

\section{Catatan :}

1. Garis bilangan digunakan sebagai media untuk menunjukan nilai mutak.

2. Tanda panah sering digunakan untuk menentukan nilai mutlak, pada arah kiri menunjukkan nilai mutlak dari angka tersebut negatif dan arah ke kanan menunjukkan nilai mutlak dari angka positif..

3. Nilai mutlak dalam hal panjang anak panah akan dihitung dari angka nol.

Garis bilangan tersebut dapat dijelaskan sbb:

Garis bilangan 1: panah bergerak kearah kanan dimulai dari angka 0 menuju angka 2 dan banyak langkah yang dilalui panah adalah 2 hal ini berarti nilai $|2|=2$ atau berjarak 2 satuan dari bilangan nol

Garis bilangan 2: panah bergerak kearah kanan dimulai dari bilangan 0 menuju angka -4 dan banyak langkah yang dilalui panah adalah 4 hal ini berarti nilai $|-4|=$ 4 atau berjarak 4 satuan dari bilangan nol

Berdasarkan penjelasan diatas, dapat dituliskan bentuk nilai mutlak sebagai berikut.

\section{Definisi}

Misalkan $\mathrm{X}$ bilangan riil, nilai mutlak pada suatu angka $\mathrm{X}$ ditulis dengan $|X|$ dan di definisikan:

$$
|X|=\left\{\begin{array}{c}
x, \text { jika } x \geq 0 \\
-x, \text { jika } x<0
\end{array}\right.
$$

Dalam sehari-hari, definisi berikut dapat diungkapkan sebagai berikut.

Nilai mutlak angka positif dan nol adalah angka itu sendiri, sedangkan bagian nilai mutlak pada suatu angka negatif adalah lawan dari angka negatif itu.

Berdasarkan defiisi tersebut, terlihat bahwa nilai mutlak suatu angka selalu positif atau nol. Bagaimana cara menggambar grafik fungsi nilai mutlak? Berikut akan digambar grafik fungsi $\mathrm{f}(\mathrm{x})=\left\{\begin{array}{c}x, \text { jika } x \geq 0 \\ -x, \text { jika } x<0\end{array}\right.$

Perhatikan langkah-langkah berikut!

\section{Langkah 1}

Buat tabel untuk menunjukan pasangan beberapa titik yang mewakili grafik tersebut!

\begin{tabular}{|c|c|c|c|c|c|c|c|c|c|c|c|}
\hline $\mathrm{X}$ & -5 & -4 & -3 & -2 & -1 & 0 & 1 & 2 & 3 & 4 & 5 \\
\hline $\mathrm{Y}=\mathrm{f}(\mathrm{X})$ & 5 & 4 & 3 & 2 & 1 & 0 & 1 & 2 & 3 & 4 & 5 \\
\hline$(\mathrm{X}, \mathrm{Y})$ & $(-5,5)(-4,4)(-3,3)(-2,2)$ & $(-1,1)$ & $(0,0)(1,1)$ & $(2,2)(3,3)$ & $(4,4)$ & $(5,5)$ \\
\hline
\end{tabular}

Gambar 3. Titik yang mewakili grafik

\section{Langkah 2}

Menyajikan titik-titik yang diperoleh pada tabel ke dalam koordinat Cartesius

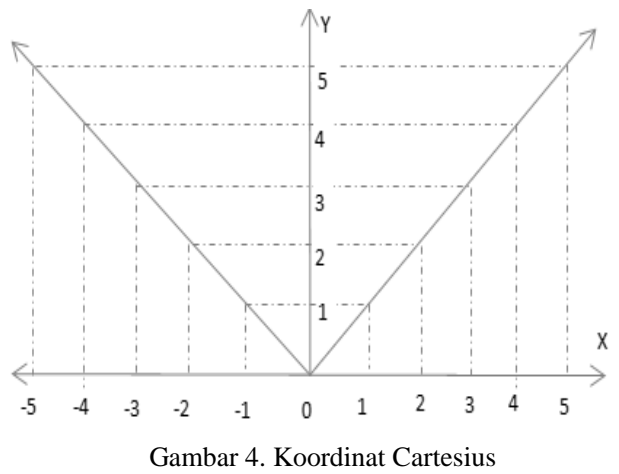

Berdasarkan definisi grafik dapat disimpulkan bahwa nilai $|X|$ pada dasarnya menyatakan besarnya penyimpangan pada titik $\mathrm{x}=0$ berdasarkan gambar diatas adakah hubungan antara $\sqrt{X^{2}}$ dan $|X|$ ?

Perhatikan tabel berikut!

\begin{tabular}{|l|l|l|l|l|l|l|l|l|l|l|l|}
\hline $\mathrm{X}$ & -5 & -4 & -3 & -2 & -1 & 0 & 1 & 2 & 3 & 4 & 5 \\
\hline $\mathrm{X}^{2}$ & 25 & 16 & 9 & 4 & 1 & 0 & 1 & 4 & 9 & 16 & 25 \\
\hline$\sqrt{X^{2}}$ & 5 & 4 & 3 & 2 & 1 & 0 & 1 & 2 & 3 & 4 & 5 \\
\hline$|X|$ & 5 & 4 & 3 & 2 & 1 & 0 & 1 & 2 & 3 & 4 & 5 \\
\hline
\end{tabular}

Gambar 5. Tabel hubungan antara $\sqrt{X^{2}}$ dan $|X|$

Berdasarkan tabel diatas dapat disimpulkan bahwa $|X|=$ $\sqrt{X^{2}}$

\section{Contoh Soal}

Seorang anak bermain lmpat-lompatan dihalaman rumah. Dari posisi diam, si anak lompat 2 langkah ke depan, kemudian 5 langkah kebelakang, dilanjutkan 3 langkah kedepan, kemudian 1 langkah kedepan, dan akhirnya 4 langkah kebelakang. Berapa langkah yang dijalani anak tersebut?

\section{Penyelesaian.}

Misalkan didefinisikan lompatan kedepan adalah searah sumbu X positif dan lompatan kebelakang searah dengan sumbu $x$ negatif.

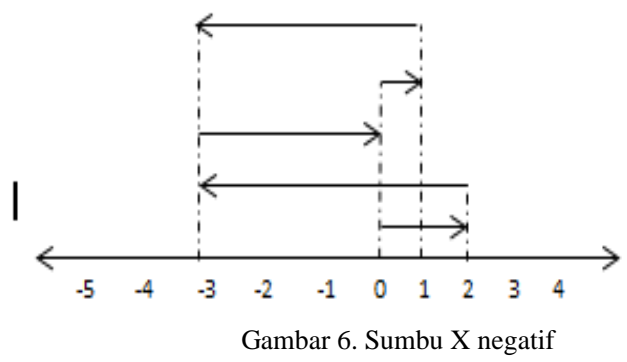

Banyaknya langkah yang dijalani si anak merupakan konsep nilai mutlak karena hanya menghitung banyak 
langkah, bukan arahnya jadi, banyak langkah anak tersebut adalah sebagai berikut.

$$
\begin{gathered}
|2|+|-5|+|3|+|1|+|-4|=2+5+3+1+4 \\
=15 \text { langkah }
\end{gathered}
$$

\section{B. Persamaan Nilai Mutlak linear Satu Variabel}

1. Menyelesaikan Persamaan Nilai Mutlak linear Satu Variabel Menggunakan Definisi Nilai Mutlak Misalkan diketahui Persamaan linear yang melibatkan nilai mutlak yaitu $|x-p|=q$, maka untuk menyelesaikannya digunakan definisi nilai mutlak sebagai berikut.

$|x-p|=\left\{\begin{array}{c}x-p, \text { untuk } x \geq p \\ -x+p, \text { untuk } x<p\end{array}\right.$

Sifat-sifat persamaan nilai mutlak untuk setiap a, b, c dan $\mathrm{x}$ bilangan riil dengan $\mathrm{a} \neq 0$.

a. Jika $|a x+b|=c$ dengan $\mathrm{c} \geq 0$, berlaku salah satu sifat berikut.
1. $a x+b=c$, untuk $\geq x-\frac{b}{a}$
2. $-(a x+b)=c$, untuk $\geq x-\frac{b}{a}$

b. Jika $|a x+b|=c$ dengan $\mathrm{c}<0$, tidak ada bilangan riil $\mathrm{x}$ yang memenuhi persamaan $|a x+b|=c$

\section{Contoh Soal}

1. Tentukan nilai $\mathrm{x}$ yang memenuhi persamaan $|x-2|=5$ !

\section{Penyelesaian}

Dengan definisi nilai mutlak diperoleh

$|x-2|=\left\{\begin{array}{c}x-2, \text { untuk } x \geq 2 \\ -x+2, \text { Untuk } x<2\end{array}\right.$

Sehingga

a. Untuk $\mathrm{x}<2$

$$
-x+2=5 \Leftrightarrow-x=3 \Leftrightarrow x=-3
$$

(memenuhi karena $\mathrm{x}=-3$ berada pada domain $\mathrm{x}<2$ )

b. Untuk $\mathrm{x} \geq 2$

$$
x-2=5 \Leftrightarrow x=7
$$

(memenuhi karena $\mathrm{x}=7$ berada pada domain $\mathrm{x} \geq 2$ )

Jadi nilai $x$ yang memenuhi adalah -3 dan 7

\section{POWERPOINT DAN APLIKASI TAMBAHAN ISPRING}

Dalam microsoft powerpoint banyak fitur-fitur yang bisa menunjang dalam pembuatan presentasi materi pelajaran ayang akan disamapaikan kepada peserta didik. Adapun beberapa fitur yang ada dalam powerpoint adalah sebagai berikut [20] :

1. Mengatur teks

2. Menambah Slide baru

3. Menyimpan dokumen

4. Mengatur Background

5. Menampilkan slide

6. Menyisipkan objek kedalam presentasi

7. Mengatur animasi pada slide

8. Membuat tombol navigasi
Pemberian tombol navigasi ini juga merupakan alternatif untuk menayangkan slide tanpa harus urut nomornya. Tombol navigasi dapat berisi perintah untuk berpindah ke slide tertentu, tak harus satu slide setelahnya atau satu slide sebelumnya.

[15] ISpring Presenter adalah alat yang dapat merubah file presentasi menjadi flash dengan bentuk SCORM / AICC, yang merupakan bagian yang digunakan untuk pembelajaran dengan e-learning LMS (Learning Management System). Perangkat lunak Ispring bisa di peroleh dengan versi free (gratis) dan berbayar. Versi free Ispring dapat di download pada link berikut http://www.ispringfree.com/download.html.

[15] Ispring Presenter dapat dengan mudah digabungkan dengan Microsoft PowerPoint yang dalam penggunaannya tidak terlalu rumit dan mudah dipahami bagi para pemula.

Beberapa menu Ispring Presenter adalah :

1. Ispring Presenter berfungsi sebagai add-in Powerpoint, untuk membuat file Powerpoint yang menarik dan interaktif serta berbasis Flash sehingga mudah dibuka untuk semua komputer atau platform.

2. Dikembangkan untuk mendukung e-learning. Presenter Ispring dapat memasukkan variasi media berupa gambar, tek dan soal interaktif, sehingga media pembelajaran yang dihasilkan lebih menarik antara lain mampu merekam dan sinkronisasi, penyaji video, menambah video Flash dan Youtube, impor atau rekam audio, tambahkan informasi membuat presentasi dan logo perusahaan, dan membuat navigasi dan desain yang unik [22], [23].

3. Mudah didistribusikan dalam format flash, yang dapat digunakan dimanapun dan dioptimalkan untuk web.

4. Membuat kuis dengan berbagai macam tipe soal / soal, yaitu: Benar / Salah, Pilihan Ganda, Respon berganda.

Menu utama yang ada dalam iSpring Presenter pada gambar berikut :

1. Publish yaitu mengatur publikasi presentasi.

Ada 2 langkah untuk mempublikasikan presentasi, yaitu

a. Dapat dipublikasikan cepat (Quick Publish) yaitu Publikasi ke format flashdisk dengan pengaturan yang mengikuti default program. Caranya yaitu :

1) Isi nama film Flash keluaran di bidang Judul Presentasi.

2) Tentukan lokal folder atau jaringan berbagi tempat presentasi akan disimpan.

3) Setelah selesai, pilih tombol publikasikan.

b. Publish yaitu Publikasi dengan pengaturan yang dapat ditentukan sendiri oleh pengguna dan di publikasikan dengan pengaturan yang ditentukan sendiri oleh user dibagi menjadi beberapa pilihan, yaitu 
1) Publish Presentation to my computer yaitu publikasi ke folder pada komputer.

Untuk publikasi pada bagian window terdiri dari 4 bagian , yaitu

a) General - tujuan komposisi pada saat output presentasi flash

b) Pengaturan - pada tampilan, navigasi, ukuran untuk output Flash movie.

c) Media - pilihan memperkecil ukuran untuk file gambar, audio dan video.

d) SCORM - setting learning-course.

Sedangkan pada Tab General terdiri dari :

a) Presentation Title untuk bagian judul presentasi yang ditampilkan pada Player.

b) Destination local folder untuk Folder menyimpan hasil output.

c) File name untuk Nama pada output file .swf.

d) Slide Range untuk menentukan slide yang dipublish.

e) Flash Output untuk mem-publish dalam bentuk hasil output flash akan dipublish ke LMS.

2) Publish Presentation to slideboom publikasi melalui Web/uplode presentasi pada portal online dan menampilkan pada worldwide.

3) Publish Presentation to Web/FTP menguplode presentasi ke FTP.

4) mengirim presentasi melalui email.

2. Presentation pengaturan /manajemen presentasi, presenter, dan tautan/link.

Ada 2 macam presenter yaitu :

a. Presenter manager - Presenters Tab.

Pada Presenters Tab kita bisa untuk menambahkan, mengedit, menghapus presenter atau mengatur presenter yang ditambahkan secara otomatis pada presentasi. Semua informasi tentang presenter tersimpan pada presentasi, sehingga dapat di edit dalam powerpoint. [24]

b. Presenter manager - Company Tab

Pada Company Tab dapat ditambahkan logo perusahaan dan menge-link ke web site perusahaan

3. Narration yaitu pengaturan narasi video/audio, dan sinkronisasi narasi.

Pada naration terdiri dari :

a. Audio Recording

Berfungsi merekam audio dengan cara membaca teks dengan keras dan mensinkronisasi dengan slideshow. [25]

b. Video Recording

Presentasi bisa juga ditambahkan video, menggunakan webcam dan software iSpring Presenter Master Edition.

c. Import Audio

d. Import Video e. Sinkronisasi

4. Insert untuk menyisipkan Flash, Quiz, dan video youtube.

a. Menyisipkan Flash

Digunakan menyisipkan external Flash (.swf) movie ke dalam slide Power Point.

b. Menyisipkan Quis

Menu QuizBuilder ditampilkan sebagai berikut :

1) Bagian Clipboard Terdiri dari tiga tool standar mengopi, memotong dan menempelkan potongan teks.

2) Bagian Preview melihat kuis sebelum di publish.

\section{3) Bagian Add Question} Menambahkan soal baru ke dalam kuis. Jenisjenis soal yang bisa dibuat :

a) membuat statemen benar atau salah.

b) membuat beberapa alternatif jawaban, dengan satu jawaban yang benar.

c) membuat beberapa alternatif jawaban, dengan beberapa jawaban yang benar.

d) membuat pertanyaan yang memerlukan jawaban singkat dalam area yang disediakan. Jawaban benar(kunci jawaban) yang disediakan bisa beberapa alternatif/lebih dari satu.

e) membuat soal menjodohkan

c. Menyisipkan Video Youtube

5. About yaitu untuk info tentang sofware, bantuan, dan update software.

\section{Metode PenElitian}

Metode Penelitian yang digunakan dalam penelitian ini adalah metode penelitian eksperimen dengan pendekatan kuantitatif . Bentuk metode eksperimen yang digunakan adalah menggunakan dua sampel yang saling berkorelasi (paired) yaitu sebuah sampel dengan subjek yang sama, namun mengalami dua perlakuan atau pengukuran yang berbeda [26]

Adapun desain penelitian adalah sebagai berikut:

\begin{tabular}{|c|c|c|c|c|}
\hline \multicolumn{2}{|c|}{ Kelompok } & Pretest & Perlakuan & Postest \\
\hline \multicolumn{2}{|c|}{$\mathrm{KE}$} & $\mathrm{O}_{1}$ & $\mathrm{X}$ & $\mathrm{O}_{2}$ \\
\hline \multicolumn{5}{|c|}{ Keterangan: } \\
\hline $\mathrm{KE}$ & \multicolumn{4}{|c|}{ Kelompok Eksperimen. } \\
\hline $\mathrm{X}$ & \multicolumn{4}{|c|}{ Perlakuan berupa pembelajaran menggunakan media ispring } \\
\hline $0_{1}$ & \multicolumn{4}{|c|}{ Hasil sebelum pembelajaran menggunakan media ispring } \\
\hline $\mathrm{O}_{2}$ & \multicolumn{4}{|c|}{ Hasil setelah pembelajaran menggunakan media ispring } \\
\hline
\end{tabular}

--Jurnal PETIK Volume 7, No 1, Maret 2021--76 


\section{HASIL DAN PEMBAHASAN}

Arsyad (1997) berpendapat bahwa model tutorial merupakan program pembelajaran yang digunakan untuk proses pembelajaran menggunakan perangkat lunak berupa program komputer yang berisi materi pelajaran. Sedangkan menurut Muslih (2016), Mugara (2011) bahwa tutorial adalah pembelajaran khusus dengan inkonstruksi yang terkualifikasi dan penggunaan mikrokomputer untuk tutorial secara khusus telah cukup. Tutorial dengan metode alternatif termasuk membaca, demontrasi, penentuan bacaan atau pengalaman yang membutuhkan tanggapan lisan dan tulisan, serta adanya ujian. Sebagaimana telah kita ketahui bersama tujuan pembelajaran tutorial itu "keputusan"/ pemahaman secara tuntas (mastery) kepada peserta didik mengenai materi atau bahan pelajaran yang sedang dipelajari.

A. Perbedaan Hasil Belajar Sebelum dan Sesudahnya Tutorial Pembelajaran Berbasis Ispring.

Perbedaan hasil belajar dapat dibuktikan dengan hasil pengujian hipotesis perbedaan hasil belajar sebelum dan sesudah pembelajaran menggunakan media berbasis ispring dengan uji Wilcoxon yaitu "Terdapat perbedaan hasil belajar peserta didik sebelum dan sesudah pembelajaran tutorial berbasis ispring pada pelajaran Matematika".

hamzah (2008) Pada hasil penelitian terdapat perbedaan hasil belajar sebelum peserta didik mendapatkan pembelajaran dengan menggunakan multimedia berbasis ispring, dimana dari hasil perhitungan statistik hasil pretest dan posttest, untuk data pretest dengan bentuk soal objektef skor rata-rata test 45,4 dengan jumlah data 40, standar deviasi 10,77 dan standar error mean 1,70 sedangkan untuk data posttest dengan bentuk soal objektif skor rata-rata test 86,83 jumlah data 40 dengan standar deviasi 7,66 dan standar error mean 1,21.

\section{B. Peningkatan Hasil Belajar Setelah Belajar Tutorial Berbasis Ispring.}

Perbedaan hasil belajar tersebut yaitu pada hasil belajar sesudah diberikan pembelajaran tutorial berbasis ispring lebih tinggi dibandingkan dengan skor hasil belajar sebelum pembelajaran. Dan perbedaan skor tersebut petanda adanya peningkatan hasil belajar. Adapun peningkatan hasil belajar matematika dengan pembelajaran berbasis ispring berada pada kategori tinggi, ini terbukti pada uji hipotesis peningkatan hasil belajar setelah pembelajaran tutorial berbasis ispring dengan uji t yaitu "Terdapat peningkatan prestasi belajar peserta didik dalam pembelajaran matematika melalui pembelajaran berbasis ispring ".

Peningkatan ini terbukti dari skor rata-rata awal materi persamaan nilai mutlak dalam pelajaran matematika adalah 45,4 atau 45,4\% dari skor ideal 100. Skor tersebut berarti kurang dari pencapaian kriteria ketuntasan minimal pelajaran matematika yaitu 75 , dan test akhir 86,83 atau $86,83 \%$ dari skor ideal 100 yang artinya lebih besar dari kriteria ketuntasan minimal pelajaran matematika yaitu 75 .
Dalam data tersebut terlihat bahwa, setelah kegiatan pembelajaran dilakukan, secara umum terjadi peningkatan hasil belajar rata-rata sebesar 41,43 atau sekitar $41 \%$.

C. Peningkatan Motivasi Belajar Setelah Pembelajaran Tutorial Berbasis Ispring

Untuk peningkatan motivasi belajar peserta didik setelah mendapatkan pembelajaran tutorial berbasis ispring, motivasi peserta didik meningkat sangat signifikan. [26] Hal ini dibuktikan dengan pengujian hipotesis peningkatan motivasi belajar peserta didik dimana hasil pengujiannya "Terdapat peningkatan motivasi belajar setelah peserta didik memperoleh pembelajaran tutorial berbasis ispring pada pelajaran matematika".

Dari hasil perhitungan statistik perbedaan hasil pretest dan posttest motivasi belajar, untuk data motivasi awal dengan bentuk angket skor rata-rata 39,50 dengan jumlah data 40, standar deviasi 3,367 dan standar error mean 0,53 sedangkan untuk data motivasi akhir dengan bentuk angket skor rata-rata 55,8 jumlah data 40 dengan standar deviasi 2,21 dan standar error mean 0,349.

Berdasarkan data di atas terlihat skor angket rata-rata awal pelajaran mekanika teknik adalah 39,50 atau $65,83 \%$ dari skor ideal 60. Dari data tersebut terlihat bahwa, setelah kegiatan pembelajaran dilakukan, secara umum terjadi peningkatan motivasi belajar rata-rata sebesar 16,3 atau sekitar $27,17 \%$.

\section{KESIMPULAN}

Berdasarkan pada hasil penelitian analisis data dan pembahasan yang telah dilakukan, maka peneliti dapat mengambil kesimpulan sebagai berikut:

1. Terdapat perbedaan hasil belajar peserta didik sebelum dan sesudah pembelajaran tutorial berbasis ispring pada pelajaran Matematika, maka terbukti bahwa pembelajaran tutorial berbasis ispring dapat memberikan perubahan skor yang positif dari hasil belajar sebelum diberikannya pembelajaran ke skor hasil belajar sesudah diberikan pembelajaran.

2. Pembelajaran tutorial berbasis ispring dapat meningkatkan hasil belajar peserta didik pada pelajaran Matematika. Hal tersebut didasarkan pada meningkatnya skor hasil belajar peserta didik setelah diberikan pembelajaran tutorial berbasis ispring dan peningkatan hasil belajarnya ada pada kategori tinggi.

3. Pembelajaran tutorial berbasis ispring dapat meningkatkan motivasi belajar peserta didik pada pelajaran Matematika. Hal ini didasarkan pada meningkatnya skor motivasi belajar peserta didik setelah diberikan pembelajaran tutorial berbasis ispring dan peningkatan motivasi belajarnya ada pada kategori tinggi.

4. Terdapat perbedaan motivasi belajar siswa sebelum dan sesudah pembelajaran tutorial berbasis ispring 
pada pelajaran Matematika. Hal ini berarti ketika sesudah diberikannya perlakuan dapat merubah motivasi awal sebelum pembelajaran dengan motivasi akhir setelah pembelajaran.

\section{DAFTAR PUSTAKA}

[1] Z. Haq, "Peran Guru Dan Orang Tua Dalam Meningkatkan Pembelajaran Daring Pada Mata Pelajaran Bahasa Indonesia Di Mi Nu 31 Jatipurwo Tahun Pelajaran 2020/2021,” 2020.

[2] F. Y. Widoyoko Tayibnapis, "Evaluasi Program Pembelajaran," J. Ilmu Pendidik., 2000.

[3] N. Nurkholis, "Pendidikan Dalam Upaya memajukan Teknologi," J. Kependidikan, vol. 1, no. 1, pp. 24-44, Jan. 1970, doi: 10.24090/jk.v1i1.530.

[4] Cecep Abdul Cholik, "Pemanfaatan Teknologi Informasi dan Komunikasi untuk Meningkatkan di Indonesia,” J. Ilm. Indones., 2017.

[5] M. Muslih, "Pemanfaatan Media Pembelajaran Berbasis ICT pada Lembaga Pendidikan Non-Formal TPQ," Dimas J. Pemikir. Agama untuk Pemberdaya, vol. 16, no. 2, p. 215, 2016, doi: 10.21580/dms.2016.162.1090.

[6] U. Fajarini, "Peranan Kearifan Lokal dalam Pendidikan Karakter," SOSIO Didakt. Soc. Sci. Educ. J., 2014, doi: 10.15408/sd.v1i2.1225.

[7] Sunardi, "Efektifitas pembelajaran matematika dengan model kooperatif team accelerated instruction berbantuan cd interaktif materi bangun ruang sisi datar kelas," 2014.

[8] R. Rivalina, "Kompetensi Teknologi Informasi dan Komunikasi Guru dalam Peningkatan Kualitas Pembelajaran,” J. Teknodik, vol. 18, pp. 165-176., 2014.

[9] N. H. \& C. Suhana, Konsep strategi pembelajaran, T 371.1 Ha. Bandung: Refika Aditama, 2009.

[10] Unesco., Teknologi Komunikasi dan Informasi dalam Pendidikan: kurikulum dan untuk sekolah dan program pengembangan guru. Alih Bahasa Rusli, no. 2002. 2011.

[11]S. V. Dewi, "Efektivitas penggunaan media Screencast O-Matic pada mata kuliah kalkulus integral terhadap hasil belajar mahasiswa," $J$. Penelit. Pendidik. dan Pengajaran Mat., vol. 2, no. 1, pp. 61-66, 2016.

[12] V. A. Rochma and M. Ibrahim, "Pengembangan Media Pembelajaran Berbasis ISPRING Suite 8 Untuk Siswa Kelas X SMA," J. UNESA, 2019.

[13]M. Istiqlal, "Pengembangan Multimedia Interaktif Dalam Pembelajaran Matematika,” JIPMat, vol. 2, no. 1, 2017, doi: 10.26877/jipmat.v2i1.1480.

[14]N. R. Kusuma, muh. K. Mustami, and O. Jumadi, "Pengembangan Media Pembelajaran intearktif Power Point Ispring Suite 8 Pada Konsep Sistem Eksresi di Sekolah Menengah Atas," J. Chem. Inf. Model., 2019.
[15]D. Rusman, Pembelajaran Berbasis Teknologi Informasi dan Komunikasi. jakarta: PT Raja Grafindo Persada., 2011.

[16]L. Lia, "Multimedia Interaktif Sebagai Salah Satu Alternatif Pembelajaran Dalam Bidang Pendidikan Sains," J. Inov. Dan Pembelajaran Fis., vol. 2, no. 2, pp. 132-140, 2016.

[17] U. Muhayat, W. Wahyudi, H. Wibawanto, and W. Hardyanto, "Pengembangan Media Edukatif Berbasis Augmented Reality untuk Desain Interior dan Eksterior," Innov. J. Curric. Educ. Technol., vol. 6, no. 2, pp. 39-48, 2017, doi: 10.15294/ijcet.v6i2.19337.

[18]C. H. (2017) Hwang, G. J., \& Chen, "Influences of an inquiry based ubiquitous gaming design on students' learning achievements, motivation, behavioral patterns, and tendency towards critical thinking and problemsolving. British Journal of Educational Technology,”信阳 师范学院， vol. 1, no. 1, pp. 287-295, 2017, doi: 10.1016/j.sbspro.2015.04.758.

[19] N. Yuniasih, R. N. Aini, and R. Widowati, "Pengembangan Media Interaktif Berbasis Ispring Materi Sistem Pencernaan Manusia Kelas V Di SDN Ciptomulyo 3 Kota Malang,” J. Inspirasi Pendidik., 2018, doi: 10.21067/jip.v8i2.2647.

[20]D. Darmawan, Komunikasi Pendidikan Perspektif Bio-komunikasi. Bandung: Remaja Rosdakarya, 2015.

[21]F. Liu, "Construction of the Teaching Model of Second Classroom of Translation Based on Network Platform," Open J. Soc. Sci., vol. 07, no. 02, pp. 167-177, 2019, doi: 10.4236/jss.2019.72014.

[22]E. A. Ensher, "E-mentoring as a Critical E-learning Approach: The Impact of Social Presence on E-mentoring," Commun. Netw., vol. 05, no. 03, pp. 1-3, 2013, doi: 10.4236/cn.2013.53b1001.

[23]S. A. Allen WA, "Effects of video podcasting on psychomotor and cognitive performance, attitudes and study behavior of student physical therapists.," vol. 49, pp. 401-414, 2012.

[24]H. Salmilah, "Model Pembelajaran Inovatif Berbasis ICT (Information Communication Technology) Oleh : Hj. Salmilah, S.Kom * Abstrak:," Ulul Albab, vol. 12, no. 2, pp. 10-25, 2010.

[25]D. Darmawan, "Digital Media Communication Through Multilog Record Relevision (MRT) for Learning Content,” p. 2019, 2019.

[26]R. (2014). Sundayana, Statistika Penelitian Pendidikan. Bandung: Alfabeta.

[27] Sugiyono, "Metode Penelitian Kuantitatif, Kualitatif dan R \& D.Bandung:Alfabeta.," Metod. Penelit. Kuantitatif, Kualitatif dan R D.BandungAlfabeta., 2012, doi: 10.1017/CBO9781107415324.004.

[28]A. Arsyad, Media pembelajaran. Jakarta: Raja Grafindo Persada, 1997.

[29]R. Mugara, "Meningkatkan kompetensi guru melalui penguasaan teknologi informasi dan komunikasi (TIK).," Prodi Pengemb. Kurikulum. Univ. Pendidik. Indones. Sunan KalijagaYogyakarta., p. 
p-ISSN : 2640-7363

e-ISSN : 2614-6606

$2011,2011$.

[30] b hamzah, Model Pembelajaran Menciptakan Mroses Belajar Mengajar yang Kreatif dan Efektif. Jakarta, 2008. 